\title{
Sulphur deprivation limits Fe-deficiency responses in tomato plants
}

\author{
Sabrina Zuchi $\cdot$ Stefano Cesco $\cdot$ Zeno Varanini $\cdot$ \\ Roberto Pinton $\cdot$ Stefania Astolfi
}

Received: 12 February 2009 / Accepted: 6 March 2009 / Published online: 7 April 2009

(C) Springer-Verlag 2009

\begin{abstract}
The aim of this work was to clarify the role of S supply in the development of the response to Fe depletion in Strategy I plants. In S-sufficient plants, Fe-deficiency caused an increase in the Fe(III)-chelate reductase activity, ${ }^{59} \mathrm{Fe}$ uptake rate and ethylene production at root level. This response was associated with increased expression of LeFRO1 [Fe(III)-chelate reductase] and LeIRT1 $\left(\mathrm{Fe}^{2+}\right.$ transporter) genes. Instead, when S-deficient plants were transferred to a Fe-free solution, no induction of $\mathrm{Fe}(\mathrm{III})$ chelate reductase activity and ethylene production was observed. The same held true for LeFRO1 gene expression, while the increase in ${ }^{59} \mathrm{Fe}^{2+}$ uptake rate and LeIRT1 gene over-expression were limited. Sulphur deficiency caused a decrease in total sulphur and thiol content; a concomitant increase in ${ }^{35} \mathrm{SO}_{4}{ }^{2-}$ uptake rate was observed, this behaviour being particularly evident in Fe-deficient plants. Sulphur deficiency also virtually abolished expression of the nicotianamine synthase gene (LeNAS), independently of the Fe growth conditions. Sulphur deficiency alone also caused a decrease in $\mathrm{Fe}$ content in tomato leaves and an increase in root ethylene production; however, these events were not associated with either increased Fe(III)-chelate reductase activity, higher rates of ${ }^{59} \mathrm{Fe}$ uptake or over-expression of either LeFRO1 or LeIRT1 genes. Results show that S defi-
\end{abstract}

\footnotetext{
S. Zuchi $\cdot$ S. Astolfi $(\bowtie)$

Dipartimento di Agrobiologia e Agrochimica,

Università della Tuscia, via S. C. de Lellis,

01100 Viterbo, Italy

e-mail: sastolfi@unitus.it

S. Cesco $\cdot$ R. Pinton

DISA, University of Udine, Udine, Italy

Z. Varanini

DiSTeMeV, University of Verona, Verona, Italy
}

ciency could limit the capacity of tomato plants to cope with Fe-shortage by preventing the induction of the Fe(III)chelate reductase and limiting the activity and expression of the $\mathrm{Fe}^{2+}$ transporter. Furthermore, the results support the idea that ethylene alone cannot trigger specific Fe-deficiency physiological responses in a Strategy I plant, such as tomato.

Keywords Ethylene - Iron deficiency · Iron uptake · Sulphur deficiency $\cdot$ Strategy I $\cdot$ Tomato
Abbreviations
DW Dry weight
NS Nutrient solution
SAM $S$-adenosylmethionine

\section{Introduction}

To cope with low Fe availability in the soil, higher plants have evolved two complex mechanisms: Strategy I (all plants, except Gramineae) and Strategy II (Gramineae) (Marschner et al. 1986; Römheld 1987). Strategy I plants can mobilize and take up $\mathrm{Fe}^{3+}$ ions from soil particles by acidification of the rhizosphere, probably driven by an increased plasma membrane $\mathrm{H}^{+}$ATPase activity (Dell'Orto et al. 2000), by enhancing the activity of a plasma membranebound $\mathrm{Fe}(\mathrm{III})$-chelate reductase and by overexpression of a $\mathrm{Fe}^{2+}$ transporter of root epidermal cells (Eide et al. 1996; Robinson et al. 1999). Furthermore, some authors indicated ethylene as a possible regulator of the Fe-deficiency responses in these plants (Romera and Alcántara 2004).

Strategy II consists of the roots releasing high-affinity chelating compounds [phytosiderophores (PS)], which are able to form stable complexes with the micronutrient. 
Advances in the understanding of the metabolic responses to Fe deficiency have highlighted the key role of methionine in both Strategy I and Strategy II plants (Rudolph et al. 1985; Douchkov et al. 2002). Methionine is a S-containing amino acid required for the synthesis of protein and of S-adenosylmethionine (SAM), which is a common precursor of molecules as nicotianamine (NA), ethylene, polyamines and PS (Hesse and Hoefgen 2003). In higher plants, methionine biosynthesis involves two pathways: S assimilation and aspartate metabolism (Ravanel et al. 1998; Hesse and Hoefgen 2003). The level of free methionine is also assured by a recycling pathway known as the "Yang cycle", which conserves the methylthio group for regeneration of methionine when SAM is used for synthesis of polyamines or ethylene (Yang and Hoffman 1984). However, it has recently been demonstrated that the level of free methionine is rate limiting for ethylene production in tomato fruit and that de novo synthesis of methionine is necessary to allow the evolution of higher rates of ethylene (Katz et al. 2006).

Nicotianamine is a common component for both strategies (Rudolph et al. 1985; Douchkov et al. 2002). In Strategy I plants, NA might function as a chelator of Fe in symplastic and phloem transport, whereas in Strategy II plants, NA has been shown to be a precursor for the biosynthesis of the mugineic acid family of PS.

Taken together, this evidence suggests that sulphur availability might conceivably play a role in the Fe-deficiency responses due to the need to maintain an adequate level of methionine and its derivatives.

Interactions between $\mathrm{S}$ and Fe nutrition have been shown in Strategy II plants (Kuwajima and Kawai 1997; Astolfi et al. 2003, 2004, 2006a, b; Bouranis et al. 2003), indicating that $\mathrm{S}$ deficiency could limit Fe-deficiency response through a decrease in the production and release of PS.

This aspect is a matter of concern as $\mathrm{S}$ availability is limited in some soils and S-deficient areas are becoming widespread due both to reduced $\mathrm{SO}_{2}$ atmospheric inputs caused by strict emission regulation and to changes in agronomic practices, such as use of high-analysis low-S fertilizers and declining use of S-containing fungicides (McGrath and Zhao 1995; McGrath et al. 1996).

The aim of this work was to clarify the role of S supply in the development of the response to Fe depletion in Strategy I plants. In particular, we investigated changes in several components of Strategy I response at root level of tomato plants, including ethylene production, $\mathrm{Fe}$ (III) reducing activity and ${ }^{59} \mathrm{Fe}$ uptake. In addition, the expression of the $\mathrm{Fe}(\mathrm{III})$-chelate reductase $(\mathrm{LeFROI})$ and $\mathrm{Fe}^{2+}$ transporter (LeIRT1) genes at root level was analysed. Due to the role of NA in Fe nutrition and its production from sulphur-containing compounds, nicotianamine-synthase gene (NAS) expression was also evaluated together with some parame- ters related to sulphur nutritional status (total sulphur and thiol contents, ${ }^{35} \mathrm{SO}_{4}=$ uptake).

\section{Materials and methods}

\section{Growing conditions}

Tomato (Solanum lycopersicum L., cv. Gimar, kindly provided by Prof. Soressi, DABAC, University of Viterbo) was used as Strategy I model plant. Seedlings were hydroponically grown in plastic pots (six seedlings per pot) containing 2.51 of nutrient solution (NS) (Zhang et al. 1991) for 7 days, being exposed to $1.2 \mathrm{mM}$ sulphate and $40 \mu \mathrm{M}$ $\mathrm{Fe}^{\mathrm{III}}$-EDTA. Half of the plants were then transferred for a further week to a S-free nutrient solution (NS). Thereafter, half of the plants deriving from the two $S$ growth conditions $(+\mathrm{S}$ and $-\mathrm{S})$ were transferred to a Fe-free NS.

In $\mathrm{S}$-free $\mathrm{NS}$, sulphate salts $\left(\mathrm{K}^{+}, \mathrm{Mn}^{2+}, \mathrm{Zn}^{2+}, \mathrm{Cu}^{2+}\right)$ were replaced by appropriate amounts of the corresponding chloride salts $\left(\mathrm{K}^{+}, \mathrm{Mn}^{2+}, \mathrm{Zn}^{2+}, \mathrm{Cu}^{2+}\right)$. NS was continuously aerated and changed every 2 days. Plants were grown in a growth chamber under $200 \mu \mathrm{mol}$ photons $\mathrm{m}^{-2} \mathrm{~s}^{-1} \mathrm{PPF}$ and $14 \mathrm{~h} / 10 \mathrm{~h}$ day/night regime $\left(27 / 20^{\circ} \mathrm{C}\right.$ day/night temperature cycling; $80 \%$ relative humidity). Both leaves and roots were harvested 17 days after sowing.

\section{Measurement of ethylene production}

For measurement of ethylene production, the whole root system was excised 4 days after the onset of the Fe deprivation treatment and placed in a test tube $(50 \mathrm{ml})$. The tubes were sealed with rubber caps and incubated in the dark at $24^{\circ} \mathrm{C}$ for $2 \mathrm{~h}$. Gas samples $(1 \mathrm{ml})$ were withdrawn from the tube through a syringe and analysed for ethylene by a gas chromatograph (Fraetovap 4200, Carlo Erba, Milano, Italia) equipped with a 80100 mesh alumina column. After ethylene analysis, the roots were weighed and the fresh weight was used to calculate the rate of ethylene production.

Measurements of ${ }^{59} \mathrm{Fe}$ uptake

To measure the capacity of the root apparatus to absorb ${ }^{59} \mathrm{Fe}$ from ${ }^{59} \mathrm{Fe}$-hydroxide, roots of intact tomato plants were washed with micronutrient-free NS for $30 \mathrm{~min}$ and then transferred to beakers containing $200 \mathrm{ml}$ of a freshly prepared micronutrient-free NS (uptake solution) buffered at pH 7.5 with $10 \mathrm{mM}$ Hepes-KOH. ${ }^{59} \mathrm{Fe}$-hydroxide was prepared as described by Cesco et al. (2000), by dissolving ${ }^{59} \mathrm{FeCl}_{3}$ in water and then adding $\mathrm{KOH} 1 \mathrm{~N}$ to raise alkaline $\mathrm{pH}$ (specific activity $123 \mathrm{kBq} \mu \mathrm{mol}^{-1} \mathrm{Fe}$ ). The experiment was started by the addition of $1 \mathrm{ml}$ of suspension containing 
${ }^{59} \mathrm{Fe}$-hydroxide $(2 \mu \mathrm{mol} \mathrm{Fe})$ to the uptake solution, and lasted for $24 \mathrm{~h}$.

Uptake of $\mathrm{Fe}^{2+}$ was assayed as described by Zaharieva and Römheld (2000) with slight modifications. The radiolabelled stock solution was prepared by adding freshly made $10 \mathrm{mM}$ ascorbate to an appropriate volume of ${ }^{59} \mathrm{FeCl}_{3}$ to reduce $\mathrm{Fe}^{3+}$ to $\mathrm{Fe}^{2+}$. An appropriate volume of freshly prepared $10 \mathrm{mM} \mathrm{FeSO}_{4}$ in $0.04 \mathrm{~N} \mathrm{HCl}$ was subsequently added. The uptake solution $(200 \mathrm{ml})$ contained $5 \mathrm{mM}$ Mes$\mathrm{KOH}$ (pH 5.5), $1 \mathrm{mM} \mathrm{CaSO}_{4}, 250 \mu \mathrm{M}{ }^{59} \mathrm{FeSO}_{4}$ (specific activity of $144 \mathrm{kBq} \mathrm{mol}^{-1} \mathrm{Fe}$ ) and $1 \mathrm{mM}$ ascorbate. The solution was aerated by bubbling. Two tomato plants were transferred into each flask, after rinsing the roots with Fefree nutrient solution for $30 \mathrm{~min}$. The experiment was started by adding ${ }^{59} \mathrm{Fe}^{\mathrm{II}}$-sulfate to the uptake solution, and lasted for $1 \mathrm{~h}$.

After the uptake periods, the plants from both radioactive experiments were transferred to a freshly prepared ${ }^{59} \mathrm{Fe}$-free nutrient solution for $10 \mathrm{~min}$ and then harvested. Root extraplasmatic ${ }^{59} \mathrm{Fe}$ pool was removed by $1.2 \mathrm{~g} \mathrm{l}^{-1}$

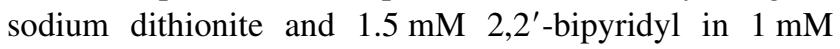
$\mathrm{Ca}\left(\mathrm{NO}_{3}\right)_{2}$ under $\mathrm{N}_{2}$ bubbling, according to the method described by Bienfait et al. (1985); the treatment was repeated three times. Roots and shoots were oven-dried at $80^{\circ} \mathrm{C}$, weighed, ashed at $550^{\circ} \mathrm{C}$ and suspended in $1 \%(\mathrm{w} / \mathrm{v})$ $\mathrm{HCl}$ for ${ }^{59} \mathrm{Fe}$ determination by liquid scintillation counting. The ${ }^{59} \mathrm{Fe}$ uptake rate, measured as $\mu \mathrm{mol}{ }^{59} \mathrm{Fe}$, is related to the whole plant (root + shoot) and is presented as per $g$ dry weight of roots $\mathrm{h}^{-1}$.

Measurements of ${ }^{35} \mathrm{SO}_{4}{ }^{2-}$ uptake

Roots of intact tomato plants were washed with micronutrient- and sulphate-free NS for $30 \mathrm{~min}$ and then transferred to beakers containing $200 \mathrm{ml}$ of a freshly prepared micronutrient- and sulphate-free $\mathrm{NS} ;{ }^{35} \mathrm{SO}_{4}{ }^{2-}$ (specific activity $2.1 \mathrm{kBq} \mu \mathrm{mol}^{-1}{ }^{35} \mathrm{SO}_{4}{ }^{2-}$ ) was added to give a final $\mathrm{SO}_{4}{ }^{2-}$ concentration of $600 \mu \mathrm{M}$. The uptake solution was buffered at $\mathrm{pH} 6.0$ with $10 \mathrm{mM}$ Mes- $\mathrm{KOH}$ and the uptake period was $1 \mathrm{~h}$. After the uptake, the plants were transferred to an ice-cold desorption solution containing $1 \mathrm{mM} \mathrm{CaSO}_{4}$ and $10 \mathrm{mM}$ Mes-KOH (pH 6.0) for 5 min. Roots and shoots were then oven-dried at $60^{\circ} \mathrm{C}$, weighed, ashed at $550^{\circ} \mathrm{C}$ and suspended in $1 \%(\mathrm{w} / \mathrm{v}) \mathrm{HCl}$ for ${ }^{35} \mathrm{SO}_{4}{ }^{2-}$ determination by liquid scintillation counting. The ${ }^{35} \mathrm{SO}_{4}{ }^{2-}$ uptake rate, measured as $\mu \mathrm{mol}{ }^{35} \mathrm{SO}_{4}{ }^{2-}$, is referred to the whole plant (root + shoot) and is presented as per $\mathrm{g}$ dry weight of roots $\mathrm{h}^{-1}$.

Determination of root ferric reductase activity

Fe(III)-EDTA reduction by roots of intact tomato plants was measured by using the bathophenanthrolinedisulfonate
(BPDS) reagent as described in Pinton et al. (1999). Briefly, roots of a single plant were placed in deionised water for $5 \mathrm{~min}$. They were then transferred to an aerated assay solution consisting of $0.5 \mathrm{mM} \mathrm{CaSO}, 0.25 \mathrm{mM}$ Fe(III)-EDTA, 0.6 mM BPDS and $10 \mathrm{mM}$ Mes at $\mathrm{pH} 5.5$ adjusted by $1 \mathrm{M} \mathrm{KOH}$, and incubated in the dark at $25^{\circ} \mathrm{C}$ for $30-60 \mathrm{~min}$. The absorbance of the assay solution was recorded by a spectrophotometer at $535 \mathrm{~nm}$ and the amount of reduced $\mathrm{Fe}$ (III) was calculated by the concentration of the $\mathrm{Fe}(\mathrm{II})-\mathrm{BPDS}_{3}$ complex using an extinction coefficient of $22.1 \mathrm{mM}^{-1} \mathrm{~cm}^{-1}$.

Total RNA extraction and RT-PCR analysis

Isolation of total RNA from the roots of tomato plants was performed using the Trizol ${ }^{\circledR}$ reagent system according to the manufacturer's instructions (Invitrogen, Carlsbad, CA, USA). One mg of DNase-treated RNA was reverse-transcribed by M-MLV (H-) Reverse Transcriptase (Invitrogen) to synthesise the first strand of cDNA. One microlitre of the oligo(dT)12-primed first strand cDNA samples was applied for PCR using reverse and forward primers designed by $\mathrm{Li}$ et al. (2004) to amplify LeIRT1 and LeFRO1 cDNA. Primers used were as follows: LeIRT1-1 primer, 5'-TGGCTGTGGCTGGAAATCATGTTC-3' and LeIRT1-2 primer, 5'-AGAATTTTTTTGCAACTCCCAA TAGGT-3'; LeFRO1-1 primer, 5'-GGAGCCAGAGAAA ATCAGTG-3' and LeFRO1-2 primer, 5'-CGAAGCCATA GGAGTTGC-3'. Reverse and forward primers to amplify LeNAS cDNA were designed on the basis of the published LeNAS gene sequence (accession no. TC178772) and were as follows: LeNAS-1 primer, 5'-TCACAGATCTTGTCCA CACG-3' and LeNAS-2 primer, 5'-CATACGGCTGGACA TGTCTG-3'. The level of the $18 S$ gene expression was used as control for quantification. PCR conditions were: 94 and $55^{\circ} \mathrm{C}$ for $45 \mathrm{~s}$ each and $72^{\circ} \mathrm{C}$ for $1 \mathrm{~min}$ for each cycle, plus a final extension time of $72^{\circ} \mathrm{C}$ for $7 \mathrm{~min}$. The number of PCR cycles was adjusted to obtain detectable amounts of amplicons without reaching signal saturation, which was accomplished with 32 cycles for LeIRT1, LeNAS and $18 S$ (control) and 45 cycles for LeFRO1. All semi-quantitative RT-PCRs were performed in duplicate. RT-PCR amplification products were separated electrophoretically on $1 \%$ (w/ v) agarose gels and stained with ethidium bromide.

Other measurements and statistics

The concentration of chlorophyll per unit area was estimated in attached leaves by a SPAD portable apparatus (Minolta Co., Osaka, Japan) using the first fully expanded leaf from the top of the plant.

To determine total $\mathrm{S}$ concentration, $1 \mathrm{~g}$ of each leaf or root sample was dried at $105^{\circ} \mathrm{C}$ and then ashed in a muffle 
furnace at $600^{\circ} \mathrm{C}$. The ashes were dissolved in $10 \mathrm{ml}$ of $3 \mathrm{~N}$ $\mathrm{HCl}$ and filtered through Whatman no. 42 paper. In contact with $\mathrm{BaCl}_{2}$, a $\mathrm{BaSO}_{4}$ precipitate is formed which is determined turbidimetrically (Bardsley and Lancaster 1962).

Water-soluble non-protein thiol compounds were determined colorimetrically with DTNB following the procedure described in Badiani et al. (1997). Briefly, leaves and roots were homogenized in a solution containing $80 \mathrm{mM}$ trichloroacetic acid, $1 \mathrm{mM}$ ethylenediaminetetraacetic acid, $0.15 \%$ (w/v) ascorbid acid and 10\% (w/v) PVP using $3 \mathrm{ml}$ buffer per $g$ as fresh weight roots. The DTNB reactive compounds were measured spectrophotometrically at $415 \mathrm{~nm}$.

To determine $\mathrm{Fe}, \mathrm{Ca}, \mathrm{Mg}, \mathrm{Na}$ and $\mathrm{K}$ content, leaf tissues were oven-dried at $80^{\circ} \mathrm{C}$ to constant weight and thereafter heated at $550^{\circ} \mathrm{C}$ for $6 \mathrm{~h}$ in a muffle furnace. The ashes were dissolved in $1 \mathrm{M} \mathrm{HCl}$ and analysed by inductively coupled plasma atomic emission spectrometry in an ICP-AES instrument (VISTA MPX, Varian, Torino, Italy).

Each reported value represents the mean \pm SD of measurements carried out in triplicate and obtained from three independent experiments. Statistical analyses of data were carried out by ANOVA tests with the GraphPad InStat Program (version 3.06). Significant differences were established by post hoc comparisons (HSD test of Tukey) at $P<0.01$ or $<0.05$.

\section{Results}

Plant growth and root morphology

Sulphur deficiency resulted in a significant decrease in fresh weight of both shoot and roots $(-40$ and $-20 \%$, respectively) (Fig. 1a, b). However, this phenomenon was mainly evident at leaf level with a consequent lowering of shoot/ root ratio (from 4.62 to 3.18 in the $+\mathrm{S}$ and $-\mathrm{S}$ plants, respectively) (box in Fig. 1b). Also the imposition of Fe deficiency significantly decreased the values of fresh weight of both leaves $(-25 \%$ in both $+\mathrm{S}$ and $-\mathrm{S}$ plants) and roots $(-30$ and $-20 \%$ in $+\mathrm{S}$ and $-\mathrm{S}$ plants, respectively). A similar behaviour was observed for dry weight (Fig. 1c, d).

As shown in Fig. 2, roots of S-sufficient plants developed several subapical swellings after imposition of $\mathrm{Fe}$ deficiency. Interestingly, subapical swellings formation did not occur upon Fe removal in plants grown in S-free nutrient solution.

The chlorophyll content was determined by chlorophyll meter readings (SPAD) that provide a sensitive and accurate index of plant response to the Fe treatment. Figure 3 shows that the levels of SPAD index were significantly decreased by $\mathrm{S}$ deficiency to $75 \%$ of the respective S-sufficient control plants, while being almost unaffected by $\mathrm{Fe}$ deficiency, probably because of the short period considered (4 days).

Plant total sulphur and thiol content, $\left({ }^{35} \mathrm{~S}\right)$-sulphate uptake rate

Total sulphur concentration was clearly much lower in S-deprived plants than in S-sufficient plants. Imposition of Fe deficiency significantly depressed sulphur content in the roots of S-sufficient plants (Fig. 4).

Concentration of non-protein thiols was also considerably decreased by $\mathrm{S}$ deprivation in both leaves and roots; however, no significant difference was observed between Fe-sufficient and Fe-deficient plants (Fig. 4).

$\mathrm{S}$ deficiency determined a significant rise in ${ }^{35} \mathrm{SO}_{4}{ }^{2-}$ uptake rate, suggesting the involvement of a response mechanism to the nutrient limitation (Table 1).

Leaf ion ( $\mathrm{Fe}, \mathrm{Ca}, \mathrm{Mg}, \mathrm{Na}$ and $\mathrm{K})$ concentration

The S-deficiency condition led to a sharp decrease in leaf $\mathrm{Fe}$ concentrations $(-59 \%)$ with respect to plants that
Fig. 1 Shoot (a) and root (b) fresh weight and shoot (c) and root (d) dry weight of S-sufficient and S-deficient tomato plants grown for 4 days with $(+\mathrm{Fe})$ or without $(-\mathrm{Fe}) 40 \mu \mathrm{M}$ FeIII-EDTA. Inserts shoot to root ratio. Data are mean $\pm \mathrm{SD}$ of three independent replications. Significant differences between samples are indicated by different letters $(P<0.01, n=3)$

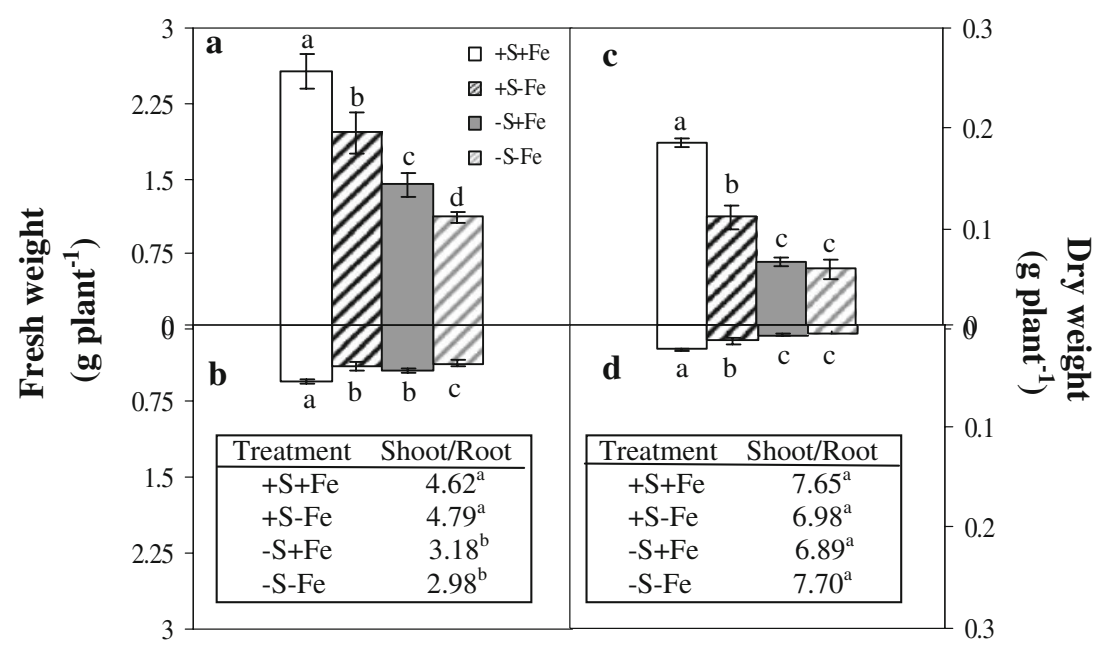


Fig. 2 Roots of S-sufficient and S-deficient tomato plants grown for 4 days with $(+\mathrm{Fe})$ or without (-Fe) $40 \mu \mathrm{M}$ FeIII-EDTA.

White circles indicate development of subapical swellings in $\mathrm{S}$-sufficient Fe-deficient $(+\mathrm{S}-\mathrm{Fe})$ roots

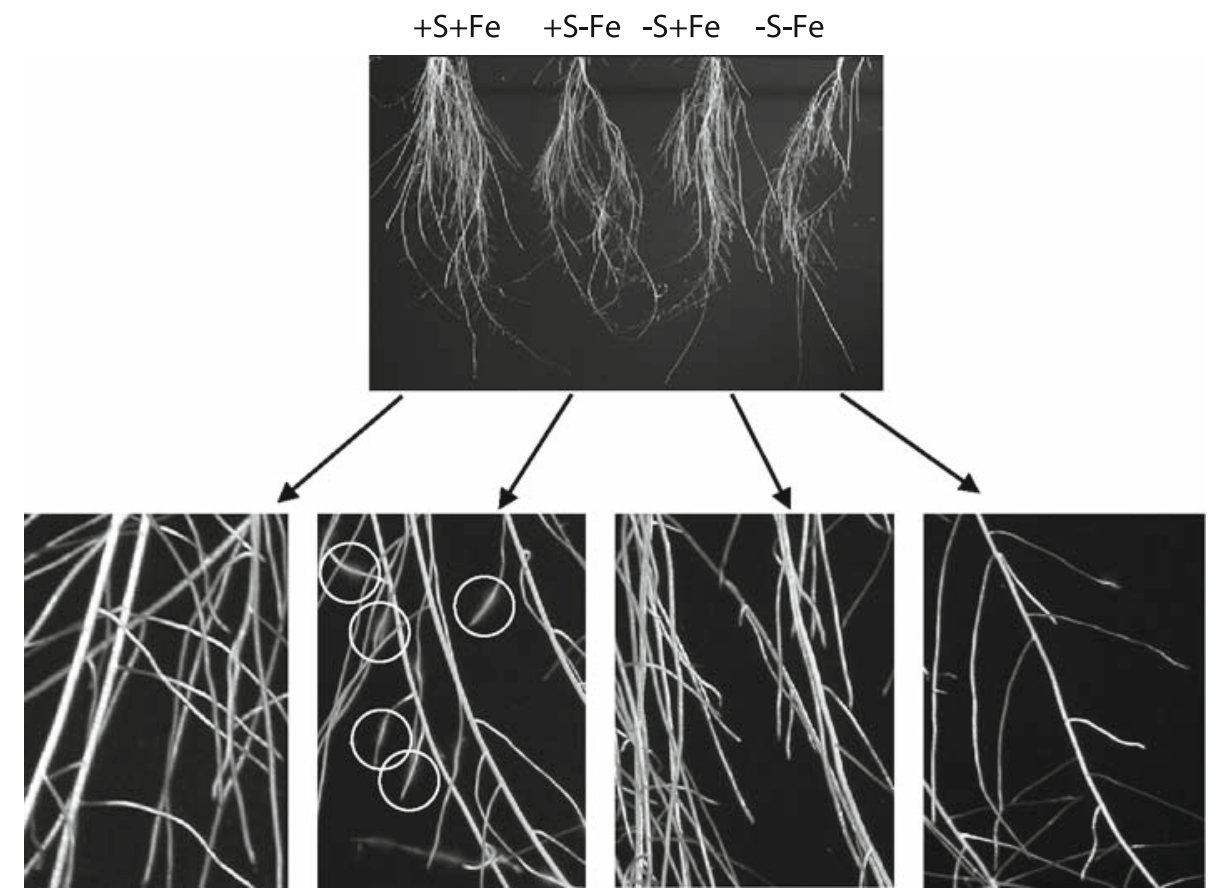

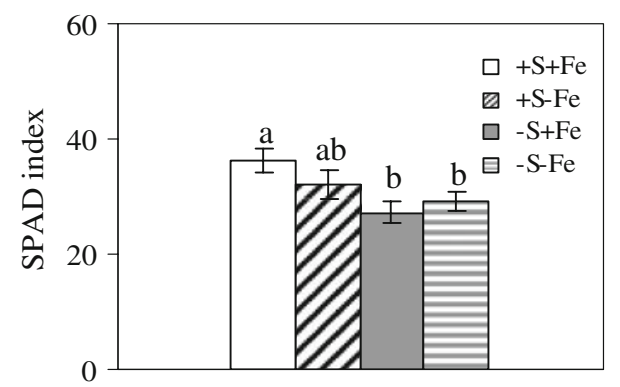

Fig. 3 Values of SPAD index of S-sufficient and S-deficient tomato plants grown for 4 days with $(+\mathrm{Fe})$ or without $(-\mathrm{Fe}) 40 \mu \mathrm{M}$ FeIII-EDTA. Data are mean \pm SD of three independent replications. Significant differences between samples are indicated by different letters $(P<0.01, n=3)$

received adequate $\mathrm{S}$ supply (Fig. 5). Essentially the same behaviour was observed when S-sufficient plants were grown for 4 days in nutrient solution without added Fe. The lowest values were observed in plants without the addition of either $\mathrm{S}$ or Fe.

On the other hand, $\mathrm{Ca}, \mathrm{Mg}, \mathrm{Na}$ and $\mathrm{K}$ contents in shoots of tomato plants grown under S-deficiency conditions were not significantly different from those measured in S-sufficient control plants (Fig. 6). In contrast, all the analysed elements tended to increase in Fe-deficient plants and reached the highest levels in plants grown without either $\mathrm{S}$ or Fe (Fig. 6).

\section{Root ethylene production}

Ethylene production in tomato roots was significantly stimulated by $\mathrm{S}$ deficiency $(60 \%$ higher than in the
S-sufficient control) (Fig. 7). Highest levels of ethylene production were recorded when S-sufficient plants were grown in Fe-deficient conditions (130\% higher than the Fe-sufficient control). The imposition of the dual deficiency produced ethylene levels which were very close to the values observed for the $\mathrm{S}$ - and Fe-sufficient control.

\section{Root Fe(III)-chelate reducing activity}

Ferric-chelate reductase activity in roots of S-sufficient and S-deficient tomato plants was studied during 6 days of $\mathrm{Fe}$ starvation (Fig. 8).

Plants adequately supplied with $\mathrm{S}$ and Fe showed a low $\mathrm{Fe}$ (III)-chelate reducing activity; when Fe was omitted from the solution the level of activity rose to a maximum 4 days after starting the treatment. Thereafter, the activity declined to values comparable with those of the $\mathrm{S}$ - and Fe-sufficient control.

When grown in a S-deficient nutrient solution, tomato plants exhibited a $\mathrm{Fe}$ (III)-chelate reducing activity even lower than that of S-sufficient controls (Fig. 8).

Similar behaviour was observed when $\mathrm{S}$ and $\mathrm{Fe}$ were both omitted from the solution.

\section{${ }^{59} \mathrm{Fe}$ uptake and translocation}

The data in Table 1 show that Fe deficiency induced a rise in the capacity of S-sufficient plants to take up ${ }^{59} \mathrm{Fe}$ from ${ }^{59} \mathrm{Fe}(\mathrm{III})$-hydroxide. Fe deficiency also caused a strong enhancement of ${ }^{59} \mathrm{Fe}^{2+}$ uptake rates. 
Fig. 4 Total S and non-protein thiol content in leaves (a and $\mathbf{c})$ and roots (b and $\mathbf{d}$ ) of S-sufficient and S-deficient tomato plants grown for 4 days with $(+\mathrm{Fe})$ or without $(-\mathrm{Fe}) 40 \mu \mathrm{M}$ FeIII-EDTA. Data are mean \pm SD of three independent replications. Significant differences between samples are indicated by different letters $(P<0.01, n=3)$

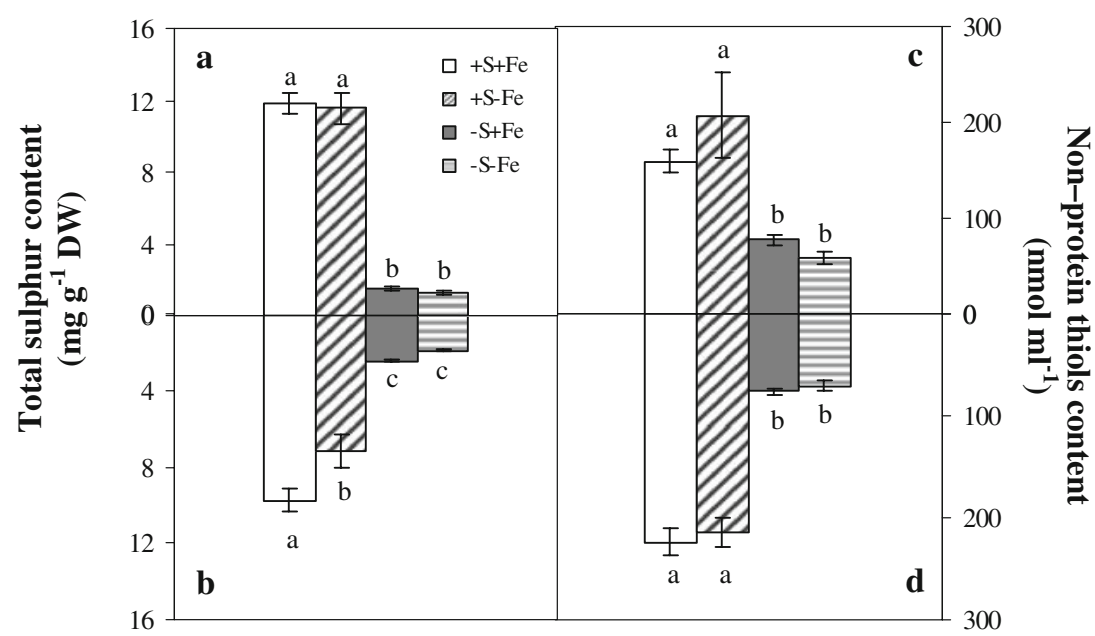

Table 1 Uptake and translocation to the shoot of ${ }^{59} \mathrm{Fe}$ from ${ }^{59} \mathrm{Fe}(\mathrm{III})$-hydroxide, and uptake of ${ }^{59} \mathrm{Fe}^{2+}$, in S-sufficient and S-deficient tomato plants grown for 4 days with $(+\mathrm{Fe})$ or without $(-\mathrm{Fe}) 40 \mu \mathrm{M} \mathrm{Fe}(\mathrm{III})-\mathrm{EDTA}$

\begin{tabular}{|c|c|c|c|c|}
\hline & \multicolumn{4}{|l|}{ Treatment } \\
\hline & $+\mathrm{S}+\mathrm{Fe}$ & $+\mathrm{S}-\mathrm{Fe}$ & $-\mathrm{S}+\mathrm{Fe}$ & $-\mathrm{S}-\mathrm{Fe}$ \\
\hline $\begin{array}{l}{ }^{59} \mathrm{Fe} \text { uptake rate from }{ }^{59} \mathrm{Fe}(\mathrm{III}) \text {-hydroxide } \\
\left(\mathrm{nmol} \mathrm{g}^{-1} \text { root } \mathrm{DW} \mathrm{h} \mathrm{h}^{-1}\right)\end{array}$ & $5.57 \pm 2.13^{b}$ & $14.93 \pm 4.12^{\mathrm{a}}$ & $4.86 \pm 1.76^{\mathrm{b}}$ & $7.58 \pm 1.70^{\mathrm{b}}$ \\
\hline $\mathrm{As}^{59} \mathrm{Fe}^{2+}\left(\mu \mathrm{mol} \mathrm{g}{ }^{-1}\right.$ root $\left.\mathrm{DW} \mathrm{h}{ }^{-1}\right)$ & $3.37 \pm 0.03^{\mathrm{c}}$ & $18.27 \pm 1.60^{\mathrm{a}}$ & $2.39 \pm 0.57^{\mathrm{c}}$ & $10.30 \pm 2.44^{\mathrm{b}}$ \\
\hline $\begin{array}{l}{ }^{59} \mathrm{Fe} \text { translocation from }{ }^{59} \mathrm{Fe}(\mathrm{III}) \text {-hydroxide } \\
\left(\mathrm{nmol}^{59} \mathrm{Fe} \mathrm{g}^{-1} \text { root } \mathrm{DW} \mathrm{h} \mathrm{h}^{-1}\right)\end{array}$ & $\begin{array}{l}2.42 \pm 1.32^{\mathrm{b}} \\
\quad(43.4 \%)\end{array}$ & $\begin{array}{l}5.65 \pm 1.71^{\mathrm{a}} \\
(37.8 \%)\end{array}$ & $\begin{array}{l}1.50 \pm 0.94^{\mathrm{b}} \\
(30.8 \%)\end{array}$ & $\begin{array}{l}1.93 \pm 0.43^{\mathrm{b}} \\
(25.5 \%)\end{array}$ \\
\hline${ }^{35} \mathrm{SO}_{4}{ }^{2-}$ uptake $\left(\mu \mathrm{mol} \mathrm{g}{ }^{-1}\right.$ root $\left.\mathrm{DW} \mathrm{h}^{-1}\right)$ & $12.9 \pm 1.3^{\mathrm{b}}$ & $12.0 \pm 1.8^{\mathrm{b}}$ & $34.4 \pm 6.9^{\mathrm{a}}$ & $47.7 \pm 13.2^{\mathrm{a}}$ \\
\hline
\end{tabular}

${ }^{59} \mathrm{Fe}$ uptake rate is referred to the whole plant (root + shoot) and reported per g dry weight of roots per hour. Uptake rates of ${ }^{35} \mathrm{SO}_{4}{ }^{2-}$ are also reported. Data are mean $\pm \mathrm{SD}$ of three independent replications

Significant differences between samples are indicated by different letters $(P<0.05, n=3)$

$\mathrm{S}$ deficiency prevented the development of a higher uptake rate in Fe-deficient plants, and also limited the development of a higher capacity to take up ${ }^{59} \mathrm{Fe}^{2+}$ in Fe-deficient plants (Table 1).

\section{Expression of LeIRT1, LeFROI and LeNAS genes in root} tissue

Expression of genes involved in Fe acquisition, such as LeIRTI $\left(\mathrm{Fe}^{2+}\right.$ transporter) and LeFROI (FeIII-reductase) was analyzed as a function of $\mathrm{Fe}$ and $\mathrm{S}$ nutrition, utilizing specific primers as described by Li et al. (2004).

Fe deficiency caused an increase in the expression levels of LeIRT1 gene; however, in S-deficient roots transcript amounts reached levels lower than those observed in S-sufficient plants either with or without Fe-supply (Fig. 9).

LeFRO1 transcript abundance was increased by Fe deficiency in S-sufficient plants, while being decreased by S-deficiency (Fig. 9).

Under unlimited S supply, LeNAS gene showed similar expression in Fe-sufficient and Fe-deficient roots (Fig. 9). S-deficiency virtually abolished NAS gene expression, independently of the $\mathrm{Fe}$ growth conditions.

\section{Discussion}

Iron-deficiency responses in Strategy I and II plants share common features: indeed, NA, a common component of both strategies, ethylene and PS are all synthesized from the S-containing amino acid methionine. This implies that reduced $\mathrm{S}$ availability might play a role in the development of an efficient response to $\mathrm{Fe}$ shortage in plants.

Interactions between $\mathrm{Fe}$ and $\mathrm{S}$ nutrition have been reported for strategy II plants. It has been demonstrated that $\mathrm{S}$ deficiency may limit the release of PS and Fe uptake in barley roots, thus leading to a reduced accumulation of $\mathrm{Fe}$ in the leaf tissue (Astolfi et al. 2006a). Furthermore, it has been shown that $\mathrm{Fe}$ deficiency caused an increase in ${ }^{35} \mathrm{SO}_{4}{ }^{2-}$ uptake rates in maize and barley plants (Astolfi et al. 2004, 2006b).

This work was aimed at assessing the role of S availability in the development of the Fe-deficiency response in tomato, a Strategy I plant.

$S$ deficiency resulted in a significant decrease in fresh and dry weight of tomato plants (Fig. 1). The shoot to root ratio calculated for fresh weight decreased as a result of a significant decrease in shoot fresh weight, reflecting a 


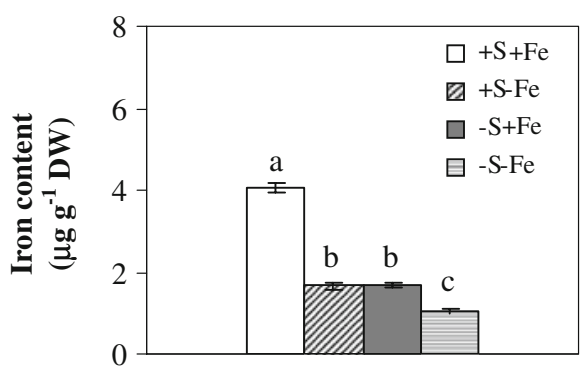

Fig. 5 Iron content in leaves of S-sufficient and S-deficient tomato plants grown for 4 days with $(+\mathrm{Fe})$ or without $(-\mathrm{Fe}) 40 \mu \mathrm{M}$ FeIII-EDTA. Data are mean \pm SD of three independent replications. Significant differences between samples are indicated by different letters $(P<0.01, n=3)$

classical response to $\mathrm{S}$ supply, as extensively reported in the literature (Robinson 1994) (box in Fig. 1).

Leaves from S-starved plants became uniformly chlorotic, as detected by SPAD readings (Fig. 3). The visual symptoms were accompanied by a strong decrease in total $\mathrm{S}$ content in the S-deprived tissues (Fig. 4a). However, we observed no further increase of leaf chlorosis upon $\mathrm{Fe}$ removal from the nutrient solution, probably because of a very short period (4 days) of Fe starvation.

Analysis of the leaf mineral composition showed that, consistent with the imposed treatment, Fe-deficient plants exhibited a marked decrease in leaf Fe content (Fig. 5). However, changes in $\mathrm{Fe}$ content in tomato leaves in the $\mathrm{Fe}$ - and in the S-starvation treatment were similar and, in particular, Fe content in S starvation leaves also decreased by nearly $60 \%$. In our previous works (Astolfi et al. 2003, 2004), we found that maize and barley plants exposed to $S$ starvation showed a lower $\mathrm{Fe}$ content than S-sufficient plants. It has been proposed that $S$ starvation might decrease the accumulation of $\mathrm{Fe}$ in the leaf tissue by inhibiting $\mathrm{Fe}$ uptake primarily as a consequence of decreasing the PS release capacity of the roots (Astolfi et al. 2006a, b).

Strategy I plants do not release PSs to cope with Fe shortage, but one of the main characteristics of their $\mathrm{Fe}$ uptake system is the increase in root ethylene production (Romera and Alcántara 1994, 2004; Romera et al. 1999). Furthermore, NA is a common component for both strate- gies (Rudolph et al. 1985; Douchkov et al. 2002). The evidence that both ethylene and NA are synthesized from methionine suggests that the observed decrease in leaf $\mathrm{Fe}$ content could probably be due to the inhibition of both uptake and translocation of $\mathrm{Fe}$ to the shoot, as a result of inadequate supply of reduced $\mathrm{S}$ to maintain the ethylene and NA biosynthetic pathway. This idea is indeed suggested by the evidence that the total sulphur content was decreased by growth under $\mathrm{Fe}$ deficiency condition in tomato roots, whereas thiol compound levels were kept constant in roots of plants grown in the absence of $\mathrm{Fe}$ (Fig. 4).

To evaluate if changes in S supply could be associated with the capacity of tomato plants to cope with Fe shortage, various components of the Strategy I mechanism were considered: root morphological changes and ethylene production, ferric reductase activity and uptake rate of Fe. Furthermore, the expression of the $\mathrm{Fe}(\mathrm{III})$-chelate reductase (LeFROI) and $\mathrm{Fe}^{2+}$ transporter (LeIRT1) genes at the root level was analysed. Due to the role of NA in Fe nutrition and its production from sulphur-containing compounds, $N A S$ expression was also evaluated together with some parameters related to sulphur nutritional status (total sulphur and thiol contents, ${ }^{35} \mathrm{SO}_{4}=$ uptake).

When grown for 4 days in a Fe-depleted nutrient solution, S-sufficient tomato plants showed a classical response to Fe deficiency (Römheld and Marschner 1981; Marschner et al. 1986; Römheld 1987), as evidenced by increased $\mathrm{Fe}$ (III)-chelate reducing capacity (Fig. 8), Fe uptake rate (Table 1) and root ethylene production (Fig. 7). These changes were accompanied by the appearance of subapical root swellings and proliferation of abundant root hairs (Fig. 2). Furthermore, the expression of both LeFROI and $I R T 1$ was greatly induced in roots in response to $\mathrm{Fe}$ deficiency (Fig. 9).

However, when plants were grown in S-deficient conditions, the response to Fe deficiency was strongly depressed: increases in ethylene production (Fig. 7), Fe(III)-chelate reductase activity (Fig. 8) and reduction based ${ }^{59} \mathrm{Fe}$ uptake (Table 1) were prevented; moreover, expression of the LeFRO1 gene was barely detectable (Fig. 9). S deficiency also limited the development of a higher activity of the $\mathrm{Fe}^{2+}$
Fig. $6 \mathrm{Ca}, \mathrm{Mg}$, Na and $\mathrm{K}$ content in leaves of S-sufficient and S-deficient tomato plants grown for 4 days with $(+\mathrm{Fe})$ or without $(-\mathrm{Fe}) 40 \mu \mathrm{M}$ FeIII-EDTA. Data are mean \pm SD of three independent replications. Significant differences between samples are indicated by different letters $(P<0.01, n=3)$

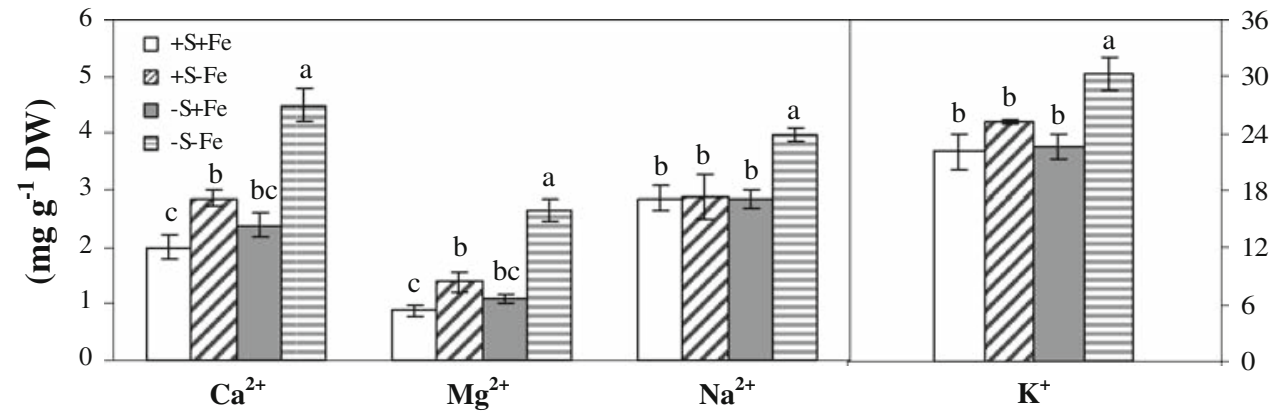




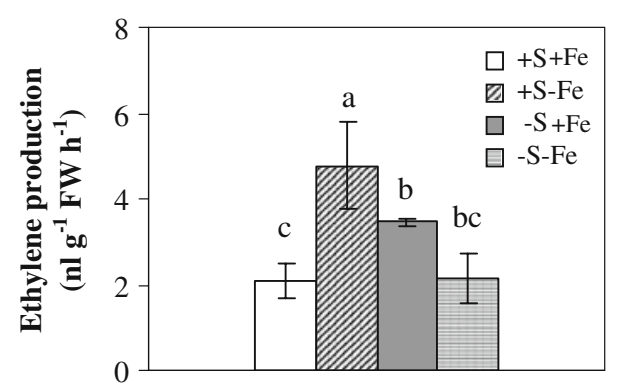

Fig. 7 Ethylene production from roots of S-sufficient and S-deficient tomato plants grown for 4 days with $(+\mathrm{Fe})$ or without $(-\mathrm{Fe}) 40 \mu \mathrm{M}$ FeIII-EDTA. Data are mean \pm SD of three independent replications. Significant differences between samples are indicated by different letters $(P<0.05, n=3)$

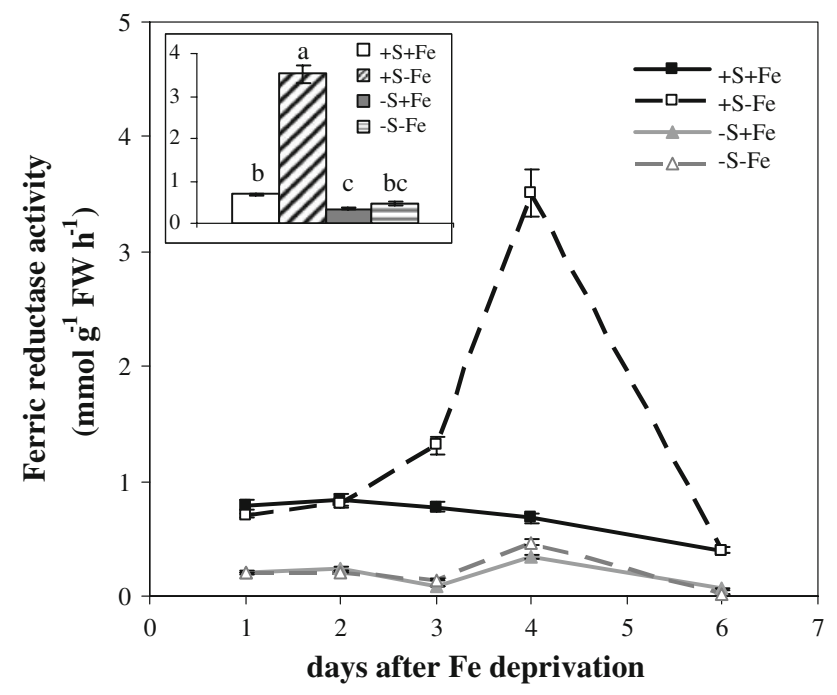

Fig. 8 Time course of changes in root $\mathrm{Fe}(\mathrm{III})$-chelate reductase activity in S-sufficient and S-deficient tomato plants grown for 4 days with $(+\mathrm{Fe})$ or without $(-\mathrm{Fe}) 40 \mu \mathrm{M}$ FeIII-EDTA. Inserts changes in root $\mathrm{Fe}(\mathrm{III})$-chelate reductase activity at the fourth day of Fe starvation. Data are mean \pm SD of three independent replications. Significant differences between samples are indicated by different letters $(P<0.01, n=3)$

transporter (Table 1) and expression of the LeIRT1 gene (Fig. 9). These data show that Fe(III)-chelate reductase activity was much more influenced by S-deficiency than $\mathrm{Fe}^{2+}$ uptake. A limited response to Fe deficiency in plants subjected to both $\mathrm{S}$ and Fe deficiency might be related to a lower demand for the micronutrient as a consequence of reduced growth rate; however, it is noteworthy that these plants were able to develop an even higher ${ }^{35} \mathrm{SO}_{4}{ }^{2-}$ uptake rate than that shown by $\mathrm{S}$-deficient $\mathrm{Fe}$-sufficient plants (Table 1). Furthermore, the concentration of several cationic nutrients was not affected by $\mathrm{S}$ deficiency and even increased when plants were simultaneously subjected to $\mathrm{Fe}$ and S deficiency (Fig. 6).

Ethylene has been indicated as a component of the complex regulation mechanism for the onset of the Fe-defi-

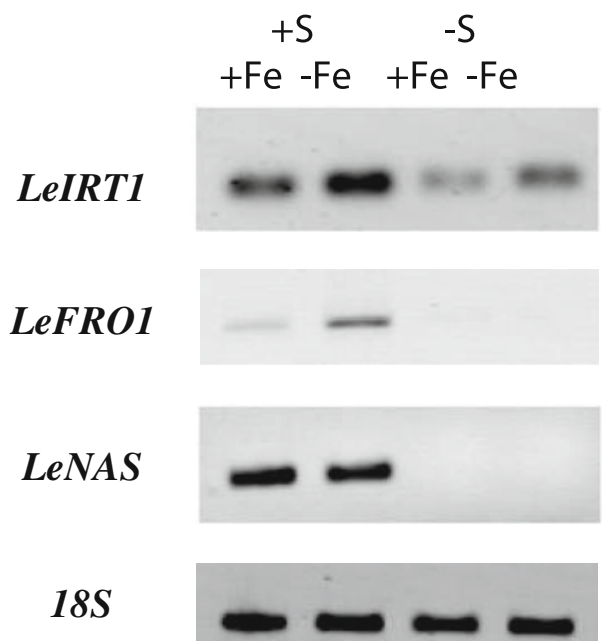

Fig. 9 RT-PCR expression analysis of iron transporter gene LeIRT1, ferric reductase gene LeFROI and nicotianamine synthase gene LeNAS in roots of S-sufficient and S-deficient tomato plants grown for 4 days with $(+\mathrm{Fe})$ or without $(-\mathrm{Fe}) 40 \mu \mathrm{M}$ FeIII-EDTA. An $18 \mathrm{~S}$ PCR product was used as a cDNA calibration control

ciency response (Schmidt 2003; Romera and Alcántara 2004). The evidence that both ethylene and NA are synthesized from methionine (Hesse and Hoefgen 2003) suggests that the observed decrease in leaf Fe content might be due to the inhibition of both uptake and translocation of $\mathrm{Fe}$ to the shoot, as a result of inadequate supply of reduced $S$ to sustain the ethylene and NA biosynthetic pathway. NAS expression was not significantly modified by $\mathrm{Fe}$ starvation in S-sufficient plants (Fig. 9), thus confirming a previous observation by Ling et al. (1999). On the other hand, NAS transcripts were virtually undetectable in S-deficient plants, irrespective of the $\mathrm{Fe}$ nutritional treatment. This effect might be related to the low Fe content of S-starved plants.

It is interesting to note that the lack of increase in ethylene production in S-deficient, Fe-deficient plants was paralleled by a lack of activation of the $\mathrm{Fe}(\mathrm{III})$-chelate reductase activity, while $\mathrm{Fe}^{2+}$ transport rate was enhanced by Fe deficiency in $\mathrm{S}$ deficient plants, although to a lesser extent than in S-sufficient plants. This result would indicate that the two components of the Fe-deficiency response [Fe(III)reduction and $\mathrm{Fe}^{2+}$ transport] are differently sensitive to (or regulated by) ethylene levels.

S deficiency alone also caused chlorosis and a decrease in Fe content of leaf tissue. In these plants a higher ethylene production with respect to S-sufficient plants was also observed. It was reported that ethylene production is increased by ammonia accumulation in plant tissue (Feng and Barker 1993). Our results seem to support this hypothesis: as the severity of S deficiency increased, protein synthesis would likely decline leading to ammonia accumulation in the plant (Nikiforova et al. 2005) and ethylene production would increase. 
However, this behaviour was not accompanied by an activation of the Fe-deficiency response mechanisms. Lower Fe accumulation might be related to an altered NA synthesis, while the lack of activation of the $\mathrm{Fe}$ (III)-chelate reductase could likely be ascribed to an adequate $\mathrm{Fe}$ status of the roots. Increased ethylene production has been observed in response to different nutritional deficiencies (Romera and Alcántara 2004 and references therein), but not necessarily related to an adaptive mechanism. Lucena et al. (2006) also showed that application of the ethylene precursor ACC to Fe-sufficient plants determined little or no induction of $\mathrm{Fe}(\mathrm{III})$-chelate reductase $(F R O)$ gene in Arabidopsis, thus suggesting that the increase in ethylene production alone is not sufficient for activation of the plasma membrane-bound enzyme.

Acknowledgments Research was supported by grants from Italian M.I.U.R.-COFIN 2006. We thank Prof. Gian Piero Soressi (Department of Agrobiology and Agrochemistry, Viterbo, Italy) for providing seeds of tomato.

\section{References}

Astolfi S, Zuchi S, Passera C, Cesco S (2003) Does the sulphur assimilation pathway play a role in the response to $\mathrm{Fe}$ deficiency in maize (Zea mays L.) plants? J Plant Nutr 26:2111-2121

Astolfi S, Zuchi S, Cesco S, Varanini Z, Pinton R (2004) Influence of iron nutrition on sulphur uptake and metabolism in maize (Zea mays L.) roots. Soil Sci Plant Nutr 50:1079-1083

Astolfi S, Cesco S, Zuchi S, Neumann G, Roemheld V (2006a) Sulphur starvation reduces phytosiderophores release by Fe-deficient barley plants. Soil Sci Plant Nutr 52:80-85

Astolfi S, Zuchi S, Cesco S, Sanità di Toppi L, Pirazzi D, Badiani M, Varanini Z, Pinton R (2006b) Fe deficiency induces sulphate uptake and modulates redistribution of reduced sulphur pool in barley plants. Func Plant Biol 33:1055-1061

Badiani M, Paolacci AR, D'Annibale A, Miglietta F, Raschi A (1997) Plant response to elevated carbon dioxide. In: Raschi A, Miglietta F, Tognetti R, Van Gardingen PR (eds) Evidence from natural springs. Cambridge University Press, Cambridge, pp $221-241$

Bardsley CE, Lancaster JD (1962) Determination of reserve sulphur and soluble sulphate in soils. Soil Sci Soc Am Proc 24:265-268

Bienfait HF, van den Briel W, Mesland-Mul NT (1985) Free space iron pools in roots. Plant Physiol 78:596-600

Bouranis DL, Chorianopoulou SN, Protonotarios VE, Siyannis VF, Hopkins L, Hawkesford MJ (2003) Leaf response of young ironinefficient maize plants to sulphur deprivation. J Plant Nutr 26:1189-1202

Cesco S, Römheld V, Varanini Z, Pinton R (2000) Solubilisation of iron by water-extractable humic substances. J Plant Nutr Soil Sci 163:285-290

Dell'Orto M, Santi S, De Nisi P, Cesco S, Varanini Z, Pinton R, Zocchi $\mathrm{G}$ (2000) Development of Fe-deficiency responses in cucumber (Cucumis sativus L.) roots: involvement of plasma membrane $\mathrm{H}^{+}$ATPase activity. J Exp Bot 51:695-701

Douchkov D, Herbik A, Koch G, Mock HP, Melzer M, Stephan UW, Baumlein H (2002) Nicotianamine synthase: gene isolation, gene transfer and application for the manipulation of plant iron assimilation. Plant Soil 241:115-119
Eide D, Broderius M, Fett J, Guerinot ML (1996) A novel ironregulated metal transport from plants identified by functional expression in yeast. Proc Natl Acad Sci USA 93:5624-5628

Feng J, Barker AV (1993) Polyamine concentration and ethylene evolution in tomato plants under nutritional stress. Hort Sci 28:109110

Ghandilyan A, Vreugdenhil D, Aarts MGM (2006) Progress in the genetic understanding of plant iron and zinc nutrition. Physiol Plant 126:407-417

Hesse H, Hoefgen R (2003) Molecular aspects of methionine biosynthesis. Trends Plant Sci 8:259-262

Katz YS, Galili G, Amir R (2006) Regulatory role of cystathionine- $\gamma$ synthase and de novo synthesis of methionine in ethylene production during tomato fruit ripening. Plant Mol Biol 61:255-268

Kuwajima K, Kawai S (1997) Relationship between sulphur metabolism and biosynthesis of phytosiderophores in barley roots. In: Ando T, Fujita K, Nae T, Matsunoto H, Nori S, Sekiya J (eds) Plant nutrition-for sustainable food production and environment. Kluwer, The Netherlands, pp 285-286

Li L, Cheng X, Ling H-Q (2004) Isolation and characterization of $\mathrm{Fe}$ (III)-chelate reductase gene LeFRO1 in tomato. Plant Mol Biol $54: 125-136$

Ling HQ, Koch G, Baumlein H, Ganal MW (1999) Map-based cloning of chloronerva, a gene involved in iron uptake of higher plants encoding nicotianamine synthase. Proc Natl Acad Sci USA 96:7098-7103

Lucena C, Waters BM, Romera FJ, García MJ, Morales M, Alcántara E, Pérez-Vicente R (2006) Ethylene could influence ferric reductase, iron transporter, and $\mathrm{H}^{+}$-ATPase gene expression by affecting FER (or FER-like) gene activity. J Exp Bot 57:41454154

Marschner H, Römheld V, Kissel M (1986) Different strategies in higher plants in mobilization and uptake of iron. J Plant Nutr 9:695-713

McGrath SP, Zhao FJ (1995) A risk assessment of sulphur deficiency in cereals using soil and atmospheric deposition data. Soil Use Manag 11:110-114

McGrath SP, Zhao FJ, Whiters PJA (1996) Development of sulphur deficiency in crops and its treatment. In: Proceedings of the fertilisers society, No. 379. The Fertilisers Society, Peterborough, UK

Nikiforova VJ, Kopka J, Tolstikov V, Fiehn O, Hopkins L, Hawkesford MJ, Hesse H, Hoefgen R (2005) Systems rebalancing of metabolism in response to sulphur deprivation, as revealed by metabolome analysis of Arabidopsis plants. Plant Physiol 138:304-318

Pinton R, Cesco S, Santi S, Agnolon F, Varanini Z (1999) Waterextractable humic substances enhance iron deficiency responses by Fe-deficient cucumber plants. Plant Soil 210:145-157

Ravanel S, Gakière B, Job D, Douce R (1998) The specific features of methionine biosynthesis and metabolism in plants. Proc Natl Acad Sci USA 95:7805-7812

Robinson D (1994) The responses of plants to non-uniform supplies of nutrients. New Phytol 127:635-674

Robinson NJ, Procter CM, Connolly EL, Guerinot ML (1999) A ferricchelate reductase for iron uptake from soils. Nature 397:694-697

Roje S (2006) S-adenosyl-L-methionine: beyond the universal methyl group donor. Phytochemistry 67:1686-1698

Romera FJ, Alcántara E (1994) Iron-deficiency stress responses in cucumber (Cucumis sativus L.) roots: a possible role for ethylene? Plant Physiol 105:1133-1138

Romera FJ, Alcántara E (2004) Ethylene involvement in the regulation of Fe-deficiency stress responses by Strategy I plants. Func Plant Biol 31:315-328

Romera FJ, Alcántara E, De La Guardia MD (1999) Ethylene production by Fe-deficient roots and its involvement in the regulation of Fe-deficiency stress responses by strategy I plants. Ann Bot 83:51-55 
Römheld V (1987) Different strategies for iron acquisition in higher plants. Physiol Plant 70:231-234

Römheld V, Marschner H (1981) Iron-deficiency-stress-induced morphological and physiological changes in root tips of sunflower. Physiol Plant 53:354-360

Rudolph A, Becker R, Scholz T, Prochàzka Z, Toman J, Macek T, Herout V (1985) The occurrence of the amino acid nicotianamine in plants and microrganisms. A reinvestigation. Biochem Physiol Pflanz 180:557-563
Schmidt W (2003) Iron solutions: acquisition strategies and signalling pathways in plants. Trends Plant Sci 8:188-193

Yang SF, Hoffman NE (1984) Ethylene biosynthesis and its regulation in higher plants. Annu Rev Plant Physiol 35:155-189

Zaharieva T, Römheld V (2000) Specific $\mathrm{Fe}^{2+}$ uptake system in strategy I plants inducible under Fe deficiency. J Plant Nutr 23:1733-1744

Zhang FS, Römheld V, Marschner H (1991) Role of the root apoplasm for iron acquisition by wheat plants. Plant Physiol 97:1302-1305 